\title{
Rewitalizacja historycznej dzielnicy Pho Hien w mieście Hung Yen
} (Wietnam)

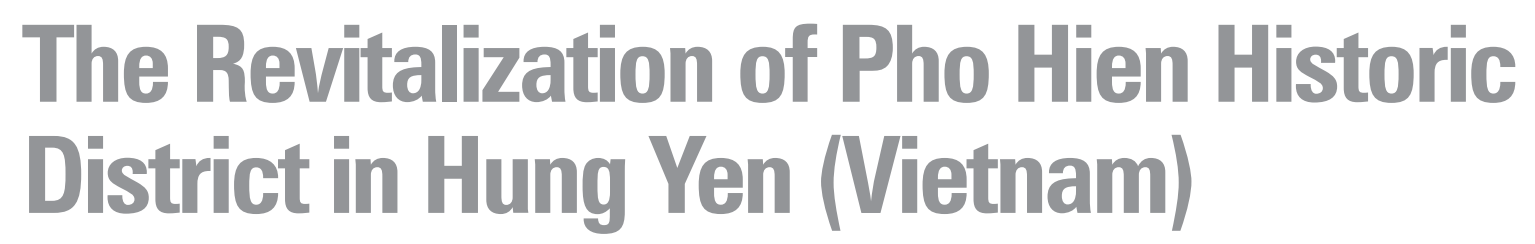

\section{Streszczenie}

Pho Hien to historyczna dzielnica Hung Yen, nowoczesnego miasta przy ujściu Czerwonej rzeki w Wietnamie. W latach 20112012 polscy architekci opracowali dla tej części program rewitalizacji i plan zagospodarowania. Program rewitalizacji miał na celu poprawę warunków mieszkaniowych oraz stworzenia tutaj centrum rekreacyjno- edukacyjnego bazującego na istniejących w mieście zabytkach i przywróceniu historii portu służącego w XVII-XVIII wieku europejskim i chińskim kupcom.

\begin{abstract}
Abstrakt
Pho Hien is a historic district of Hung Yen, a modern city situated in the mouth of the Red River in Vietnam. In the period of 2011-2012, a group of Polish architects prepared a revitalisation programme and a master plan for this district. The revitalisation programme was aimed at improving local housing as well as the creation of a cultural and education centre protecting historical monuments and recalling the historical tradition of the seventeenth and eighteenth century commercial harbour serving European and Chinese merchants.
\end{abstract}

Słowa kluczowe: Mieszkalnictwo, rewitalizacja, architektura, zabytki, Pho Hien, Hung Yen, Wietnam Key words: Housing, revitalisation, architecture, historic monuments, Pho Hien, Hung Yen, Vietnam

\begin{abstract}
Wprowadzenie
W XVII i XVIII wieku z zatoki Tonkińskiej w górę rzeki Czerwonej płynęły do portu Pho Hien statki, gdzie europejscy i chińscy kupcy mogli oczekiwać na pozwolenie udania się do Thang Long - Cha Cho (dzisiejsze Hanoi) stolicy królestwa północnego Wietnamu. (Olszewski, 1991, s. 139, 141; Tran, 2006; Pham, H., T., 2008; Schweyer, 2011, 241, 242, 318; Nguyen L., K., 2013, s. 121) $Z$ historycznej zabudowy w Pho Hien nie pozostało wiele. Mamy tutaj zaledwie kilka świątyń pochodzących z przetomu XVIII i XIX wieku. Wśród nich znajduje się jeden z najstarszych w Wietnamie kościołów chrześcijańskich. Historycznym odpowiednikiem Pho Hien w południowej części Wietnamu jest Hoi An, gdzie szczęśliwie zachował się zespół wspaniałych zabytków. Dobrze opracowany program użytkowania tego zespołu zabytkowego i walka w latach 80tych architekta Kazimierza Kwiatkowskiego o jego realizację sprawiło iż jest to obecnie miejsce wpisane na Listę światowego dziedzictwa UNESCO. (Kwiatkowski, 1990, Nguyen B., Nguyen V., P., - Hoang V., T., 2006, 131-132; Vu, 2011, s. 51-52) Po latach okazato się iż Hoi An to nie tylko jest miejscem z zabytkami do zwiedzania, ale ośrodkiem turystycznym gdzie turyści
\end{abstract}

\section{Introduction}

In the seventeenth and eighteenth centuries, ships sailed from the Gulf of Tonkin up the Red River to the port of Pho Hien, where European and Chinese merchants could wait for the permission to go to Thang Long-Cha Cho (today's Hanoi), the capital of the kingdom of Northern Vietnam (Maybon, 1910; Olszewski, 1991, p. 139, 141; Nguyen, T., H., 2006; Farrinngton 2006; Truong, 2006; Tran 2006; Hoang, 2007,Pham., 2008; Schweyer 2011, p. 241, 242, 318; Nguyen L., K., 2013, p. 121). Only a few historic monuments have remained in Pho Hien. There are only a few temples left from the turn of the eighteenth century, among them, one of the oldest Christian churches in Vietnam. Hoi An in the southern part of Vietnam, with its preserved complex of magnificent historical buildings, is a historical equivalent of Pho Hien. A well-developed usage programme drawn up for the historical complex, as well as a struggle for its implementation waged in the 1980 s by the architect Kazimierz Kwiatkowski, resulted in making the site becoming a UNESCO 


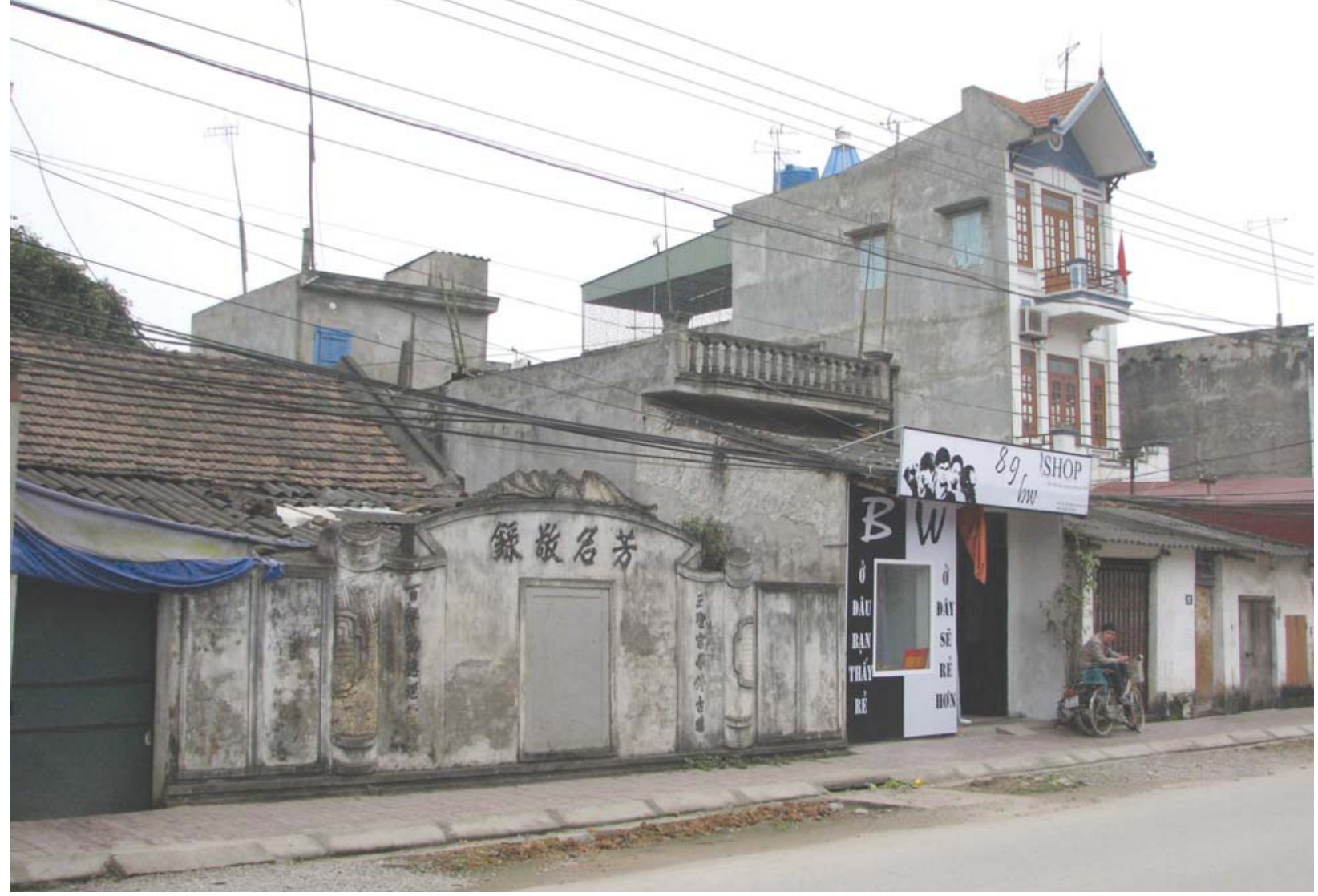

II. 1. Pho Hien, zabudowa głównej ulicy / The main street ( M. Barański)

chcą przebywać i spędzać w atrakcyjny sposób wolny czas. Władze Hung Yen chcąc wzbudzić zainteresowanie historią w regionie, a także stworzyć turystyczną atrakcję, co miałoby pobudzić rozwój lokalnej społeczności podjęły projekt rewitalizacji dzielnicy Pho Hien. Program tego projektu został określony w uchwale rządowej nr 744 z 2010 roku. Po pierwszych niezadawalających próbach wietnamskich architektów władze Hung Yen zleciły opracowanie potrzebnej dokumentacji polskiemu zespołowi. Polski zespół aktywnie działający w tym czasie w Wietnamie przedstawił m.in. koncepcję rewitalizacji

II. 2. Pho Hien, świątynia Den Ngoc Than / Temple Den Ngoc Than (M. Barański)

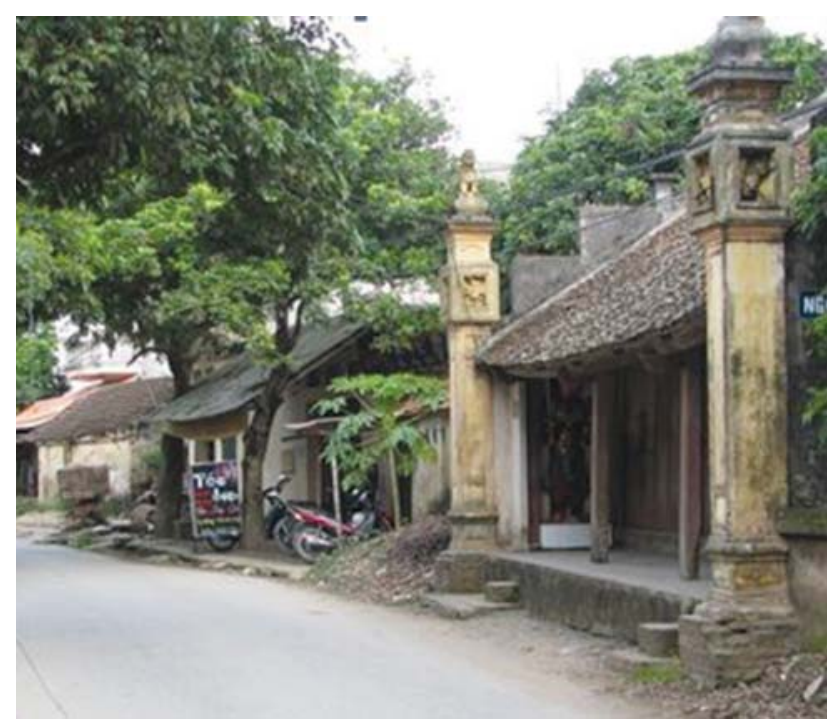

World Heritage Site in 1990 (Kwiatkowski 1990, s.51-52; Nguyen B., Nguyen V., P., - Hoang V., T., 2006, 131-132; Vu, 2011). Years later, Hoi An has turned out to be both a place with historical buildings to visit and a tourist centre, where people willingly come and spend their leisure time in an attractive way. In order to spark interest in the history of the region as well as to create a tourist attraction, which would stimulate the development of the local community, the authorities of Hung Yen launched a revitalisation project of the Pho Hien district. The programme of the project was outlined in government resolution no. 744 of 2010. After initial unsatisfactory attempts by Vietnamese architects, the authorities of Hung Yen commissioned a Polish team to prepare the necessary documentation. Active in Vietnam at that time, the Polish team drew up, among others, a revitalisation concept of the area outside the imperial palace in Hue (Barański 2016). The Pho Hien project presented a challenge in how to transform the then-unattractive suburban area with rare and underrated historical buildings into a centre which would open up an opportunity to experience its history, culture and nature. Owing to its development, the place was supposed not only to attract tourists, but also to provide new jobs.

\section{The current state of the Pho Hien district}

The district is located on the eastern outskirts of Hung Yen, along the old bed of the Yellow River. Currently, 


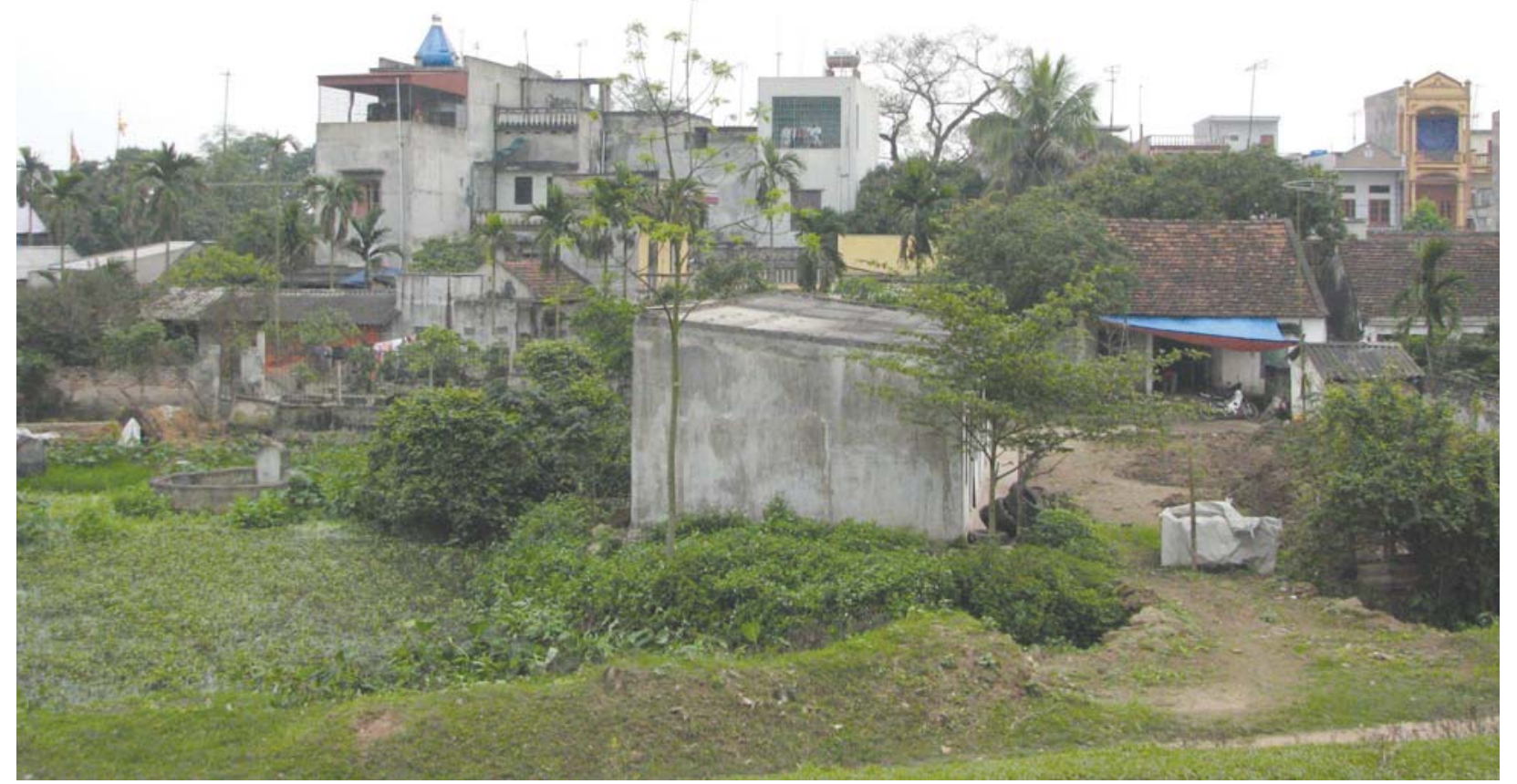

II. 3. Pho Hien, widok od strony wału rzeki Czerwonej / General view from the Red River Wall (M. Barański)

dla obszaru poza zespołem pałacu cesarskiego w Hue. (Barański 2016) Projekt Pho Hien był wyzwaniem jak przekształcić obecnie nieatrakcyjny obszar podmiejski, gdzie istniały nieliczne i niedocenione zabytki w ośrodek oferujący odwiedzającym kontakt z historią, kulturą i przyrodą. Miejsce to miało nie tylko przyciągnąć turystów, ale również poprzez swój rozwój zapewnić nowe miejsca pracy.

\section{Obecny stan dzielnicy Pho Hien}

Dzielnica położona jest na wschodnim obrzeżu miasta Hung Yen wzdłuż dawnego koryta rzeki Żółtej. Obecnie od rzeki oddziela ją wysoki wał przeciwpowodziowy. Spacerując po wale można z góry spoglądać na tę część miasta. W dzielnicy istnieją liczne oczka wodne będące świadectwem starorzecza rzeki Czerwonej. Ta część miasta obecnie posiada współczesną 2-3 kondygnacyjną zabudowę, wśród której mamy kilkanaście 100 letnich parterowych domów.

Kilka zachowanych świątyń, choć mające duże znaczenie religijne i historyczne zostało w poważny zakresie współcześnie przekształconych. Wielką atrakcją Pho Hien jest historyczne drzewo Liczi (Longan) rosnące przy jednej ze świątyń, którego owoce ze względu na unikatowy smak były dostarczane na stół cesarski. Z dzielnicy zniknęła główna największa świątynia Le Dinh Kien, która w czasie amerykańskich nalotów została zniszczona, a następnie jej obszar zajęły koszary jednostki wojskowej. Poza Pho Hien istnieje wzdłuż rzeki jeszcze kilka nie mniej cennych świątyń w tym świątynia Van Mieu jednego z najstarszych uniwersytetów w Wietnamie. Pho Hien praktycznie nie jest włączona w szlak turystyczny, zaś jedynym celem przyjeżdżających do Hung Yen pielgrzymów jest posługa religijna. Położona na obrzeżu Hung Yen zabudowa Po Hien tworzy spokojną zazielenioną enklawę, która łączy się rosnącymi na wschodzie gajami drzew Liczi (longan). Mieszkańcy tej dzielnicy przeważnie zajmują się upra- it is separated from the river by a high levee. Walking along the levee, one can admire a view of this part of the city below. The numerous oxbow lakes which can be found in the district mark out the old bed of the Red River. This part of the city currently has contemporary two- and three-storey buildings, among which there are a dozen or so 100-year-old one-storey houses.

Several preserved temples, although of considerable religious and historical significance, have been significantly transformed in modern times. (Tang 2006; Pham, H., T., 2008; Nguyen L., K., 2013, 36-44) A historical Longan tree growing near one of the temples is a great attraction of Pho Hien. Its uniquely flavoured lychee fruit were delivered to the imperial table, a fact that gave the tree its historical value. Le Dinh Kien, the main largest temple, has disappeared from the area. It was destroyed during American air raids and barracks of a military unit were constructed in its place. There are several equally valuable temples along the river outside Pho Hien, including Van Mieu, the temple of one of the oldest universities in Vietnam. Pho Hien is practically off the tourist route, and religious service is the sole objective of the pilgrims coming to Hung Yen. Situated on the outskirts of Hung Yen, the buildings of Pho Hien form a tranquil green enclave which opens out to Longan groves to the east. The inhabitants of the district mostly grow Longan trees, run their little shops and workshops. The character of this part of the city can be well illustrated by the fact that in 2011, when we started working there, there were no coffee shops in the area. We could only be treated to green tea by the local people, but to have coffee, we had to go to the centre of Hung Yen. 
wą drzew longan, prowadzą swoje sklepy i warsztaty. O charakterze tej części miasta niech świadczy fakt iż w 2011 roku gdy podjęliśmy tutaj prace nie było żadnej cafeterii. Zieloną herbatą mogliśmy być poczęstowani przez mieszkańców, lecz by napić się kawy trzeba było przejść do centrum Hung Yen

\section{Cel i program rewitalizacji Pho Hien}

Obszar Pho Hien objęty projektem miał 11 ha. Celem rewitalizacji było kompleksowe przekształcenia podmiejskiej dzielnicy Po Hien w silne atrakcyjne centrum turystyczno-kulturalne będące atrakcyjne zarówno dla przyjezdnych, jak mieszkańców i rzeszy studentów studiujących na uniwersytecie w Hung Yen. Powiązania z innymi dzielnicami miasta miało wykorzystywać bazę hotelowo-restauracyjną na większym obszarze, gdzie również znajdywały się zabytkowe budowle świątynne i kościoły. Przyczyniłoby się to do wydobycia obecnie nie eksponowanych historyczno-kulturowych wartości miasta. Koncepcję przestrzenna i program rewitalizacji Pho Hien opracował w latach 2011-2012 zespół architektów dr arch. Marek Barański, Krzysztof Jezierski, Paweł Kinsner, Marcin Binda, Maciej Zembrzuski, Hung Phung, Minh Ho Van.

Przeprowadzone studium obszaru oraz analiza potrzeb określiły zakres i kierunek działań projektowych. Zdano sobie sprawę, iż by dzielnica Pho Hien mogła stać się turystycznie atrakcyjna, a nie była jedynie miejscem krótkich wizyt turystów, należy stworzyć takie rozwiązania funkcjonalno- przestrzenne, które spowodują iż przyjeżdzający będą chcieli tutaj spędzić więcej niż 1 1/2 godziny. Krótsze pobyty nie zapewnią wystarczających przychodów, by lokalna społeczność uzyskała przychody z prowadzonej małej i dużej gastronomii, sprzedaży wyrobów regionalnych. W decyzji premiera zapisano, że poza renowacją istniejących zabytkowych świątyń i odbudowy zburzonej świątyni miało powstać tutaj centrum kultury w formie odpowiadającej dawnemu zespołowi faktorii handlowych, a także planowano zbudowanie trzech kopii XVII wiecznych statków handlowych. Zamierzenie to pozwalało na realizację unikatowego i atrakcyjnego celu turystycznego, jednak nie określało jak ono winno być skoordynowane z dzielnicą. Opracowany program rewitalizacyjny skupił się na następujących aspektach:

(1) określenie sposobu wykorzystania terenów zielonych i oczek wodnych starorzecza rzeki Czerwonej,

(2) przekształcenie istniejącej zabudowy mieszkalnej dzielnicy i wzmocnienie jej nowymi obiektami o historycznej formie, co miało powiązać zachowane tutaj lecz porozrzucane zabytki,

(3) poszerzyć zabudowę mieszkalną w miejscach dotychczas niezabudowanych,

(4) stworzyć nowe powiązania z innymi obszarami miasta, gdzie istniałaby baza hotelowa i wykorzystane byłoby zaplecze gastronomiczne dla lepszej obsługi ruchu turystycznego

(5) zaprojektować centrum edukacyjno-kulturalne jako element poszerzający potencjał historycznych innych zabytków porozrzucanych w mieście.
The objective and the programme of revitalisation of Pho Hien

The area of Pho Hien covered by the project was 11 ha. The objective of the revitalisation was to comprehensively transform the suburban district of Pho Hien into a potent, captivating tourist and culture centre which would be attractive to visitors, its inhabitants and the students of the university of Hung Yen. The project entailed the involvement of other districts of the city and using the hotel and restaurant infrastructure located there so as to draw attention to the historical temples and churches in a larger area. This would contribute to bringing to light the historical and cultural values of the city that had previously remained in a tourist void. The master plan and revitalization program of Pho Hien area were prepared in the period of 2011-2012 by architects Marek Barański, Krzysztof Jezierski, Paweł Kinsner, Marcin Binda, Maciej Zembrzuski, Hung Phung, Minh Ho Van.

A study of the area and an analysis of its needs determined both the scope and the course of the project. The analyses showed that in order to transform the Pho Hien district into a genuine tourist attraction and not just a site for short outings, it was necessary to create functional and spatial solution which would make visitors want to spend more than 1.5 hours there. Shorter stays would not provide sufficient income for the local community to earn money from their retail and largescale catering services or the sale of regional products. The prime minister's decision stated that in addition to the renovation of the existing historical temples and the reconstruction of the demolished temple, a culture centre was planned there in the form corresponding to the trading factory complex built there in the heyday of Pho Hien. Moreover, three copies of seventeenthcentury merchant ships were intended to be built. This plan enabled the creation of a unique and captivating tourist destination; however, it did not specify the way the ideas should be coordinated with the district. The developed programme of revitalisation focused on the following goals:

(1) to determine the use of green areas and oxbow lakes marking out the former bed of the Red River,

(2) to transform the existing residential development of the district and enrich it with new buildings that would have historical forms, aimed at binding together the preserved heritage buildings scattered all over the area,

(3) to expand the residential development over the undeveloped area,

(4) to create new connections with other areas of the city in order both to adopt their existing hotel infrastructure and catering facilities and to provide for the tourist industry more efficiently,

(5) to design a centre of education and culture as an element expanding the historical potential of other heritage structures scattered around the city. 


\section{Generalna koncepcja projektu}

Przeprowadzenie analizy terenowej wskazało iż historyczna ulica biegnąca przez Pho Hien będzie osia założenia, od której będą odchodzić uliczki prowadzące do stref o różnym przeznaczeniu m.in. targu, miejsc rekreacji nad wodą, centrum edukacyjno-kulturalnego. Inne uliczki powiążą dzielnice z miastem i nową zabudową oraz pozwolą na połączenie z parkingami istniejącymi w zewnętrznej strefie. Ideowo ulica Pho Hien, która miała odzyskać charakter historycznego centrum byłaby kontynuacja najbardziej atrakcyjnej promenady miasta przy której istnieją inne świątynie, oraz rozciąga się pas zieleni parkowej.

Przystępując do realizacji projektu wykonane zostało studium analityczne współczesnego funkcjonowania uliczek w historycznych ośrodkach odwiedzanych przez turystów. Do analizy porównawczej wybrano historyczne centrum Hanoi i zabudowę Hoi An. Zdano sobie sprawę, że choć w Pho Hien nie będzie możliwe konkurować z Hoi An, to jednak mamy dużą szanse stworzyć rozwiązania lepsze niż istnieją w Hanoi. Na starym mieście w Hanoi zabudowa uliczek ma monotonny charakter i na ogół poza indywidualnymi zabytkami historycznymi czy świątyniami pozbawiona jest atrakcyjnych turystycznie elementów. (Grise, Nguyen 1999, 14-22; Nguyen, B., D., Nguyen, V.,P.,- Hoang T., V., 2006, s.128-130; Phuong 2011) Historyczne centrum Hanoi chociaż posiada kontakt z przyrodą i ma liczne galerie artystyczne, to jednak poprzez olbrzymi obszar zabudowy odwiedzający to miejsce korzystają z nich w ograniczony sposób. Przy właściwym doborze rozwiązań i wprowadzeniu urozmaiconych funkcji Pho Hien ma możność stać się miejscem atrakcyjnym turystycznie. Znaczenie będzie tutaj miała
The general concept of the project

The field analysis showed that the historical street running through Pho Hien would be the axis of the complex, with streets leading to zones of various use, such as a market, places of recreation by the water and a centre of education and culture. Other streets would connect the district with the city as well as new developments and enable a connection with the car parks located in the outer zone. Conceptually, the street of Pho Hien, which was to regain its character of a historical centre, would become an extension of the most attractive city's promenade with other temples and a belt of park greenery alongside. The implementation of the project started with an analytical study of the contemporary operation of streets in other historical centres visited by tourists. The historical centre of Hanoi and the buildings of Hoi An were selected to conduct a comparative analysis. The analysis showed that although Pho Hien would not be able to compete with Hoi An, better solutions could be created there than those in Hanoi. The housing in the old town of Hanoi is monotonous, and elements attractive to tourists including a few historic monuments and temples are practically nonexistent (Grise, Nguyen N., Q., 1999, 14-22; Nguyen, Nguyen V.,-Hoang T.C., 2006, p. 128-130; Phuong, D., Q., 2011). Although the historical centre of Hanoi has green areas and numerous art galleries, tourists can use and appreciate them in a limited way, owing to the extensive area of the district. Assuming the right choice of solutions and the implementation of a vari-

II. 4. Pho Hien, Master plan. Zabudowa kolor szary obiekty istniejące, jasnobrązowa - istniejące zabytki, ciemno-brązowa - nowe obiekty / Grey - existing houses, light brown - historical monuments. Dark-brown - new buildings (M. Barański, K. Jezierski)

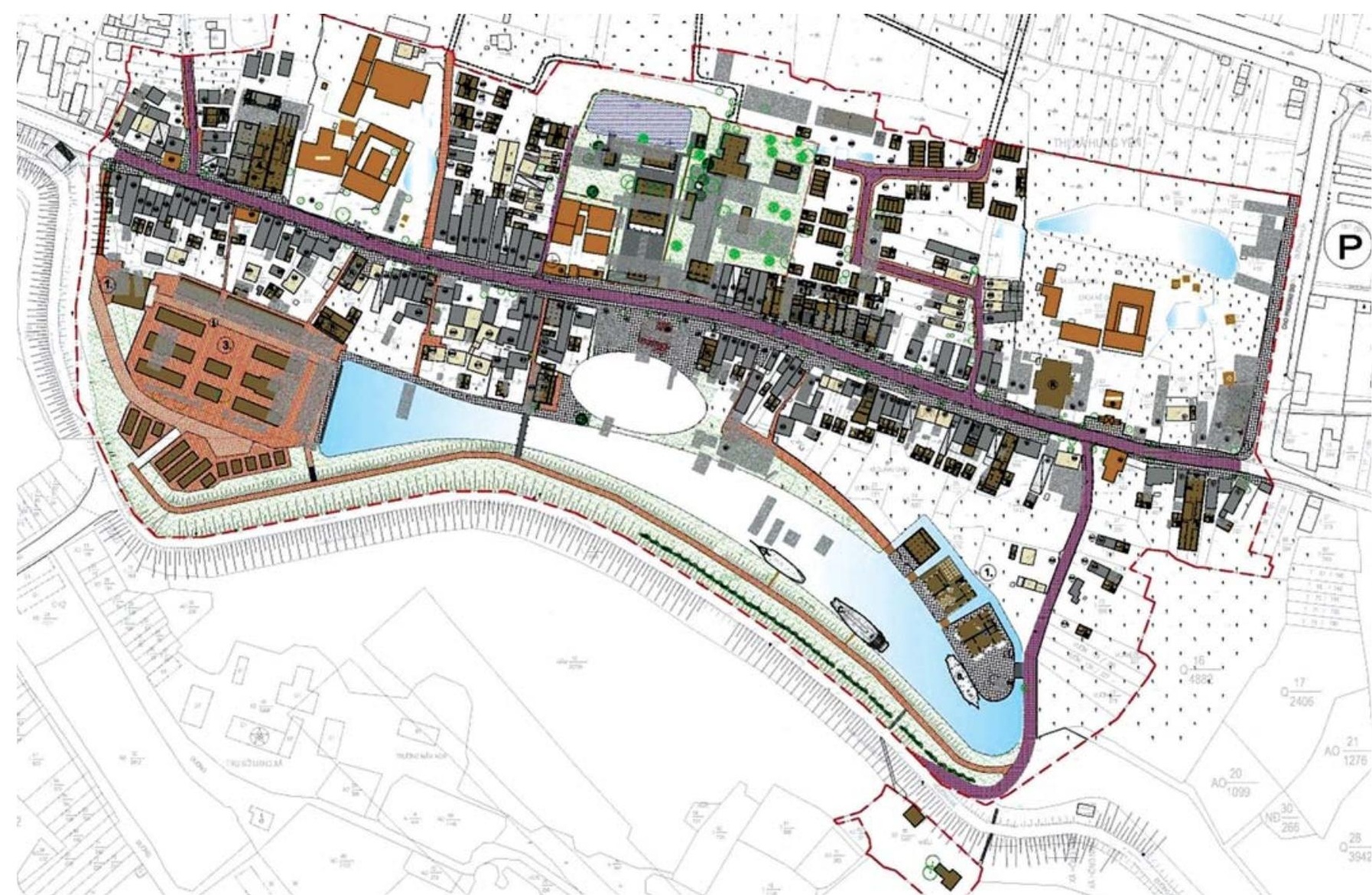


koncentracja oraz urozmaicenie oferty, a także bliski kontakt z przyrodą i unikatowe centrum edukacyjnokulturalne planowane w obiektach handlowych faktorii. Jednym z wyzwań projektu były przekształcenia istniejącej współczesnej, pozbawionej charakteru zabudowy domów jednorodzinnych, tak by mogły one uzyskać formę nawiązującą do historycznej zabudowy. Budynki te wraz z nowymi obiektami w tym również projektowanymi w formach historycznych miały tworzyć strukturę głównej ulicy Pho Hien i tworzyć łączniki do współczesnych części miasta. Ten szlak został określony jako Pho Hien Street Visitors Trail. Miał on doprowadzać za miasto do gajów drzew Longan i do historycznego centrum dawnych faktorii handlowych. Drugi szlak Natural Reserve Trail rozpoczynał by się w tym samym miejscu lecz biegł by przez targ i dalej wzdłuż wału rzeki Czerwonej doprowadzając do centrum dawnych faktorii. Oba szlaki miały być połączone między sobą co dawałoby szansę na indywidualne kreowanie własnych szlaków spacerów.

Istotnym elementem projektu rewitalizacji Pho Hien była budowa centrum dawnych faktorii handlowych. Przedstawiony w rozporządzeniu premiera Wietnamu zakres obejmował także wykonanie replik 3 dawnych statków handlowych. Dla tej części projektu przyjęto zorganizowanie tutaj centrum edukacyjno-historycznego. Pozwoliłoby to rozszerzyć turystyczne zainteresowanie dotychczas ograniczone do oglądania kilku zabytków w mieście.

\section{Rewitalizacja środowiska naturalnego}

Podjęcie projektu rewitalizacji Pho Hien związane było z przeprowadzeniem analizy materiałów historycznych oraz analiz terenowych i widokowych, tak by podróżowanie po tym zespole było atrakcyjne w każdym z miejsc. Przyjęto zasadę, że zwiedzający nie może w szybki sposób dotrzeć do celu, który pokazuje się mu w widoku. Idąc trasa miejską czy przyrodniczą odkrywałby atrakcje, które pominął wędrując pierwotnym szlakiem. Zmuszałoby by go to krążenia po centrum, gdzie odwiedzałby warsztaty rzemieślnicze na targu, lub chciałby odpocząć w atrakcyjnie położonej kawiarni nad wodą. Tym samym organizacja zieleni w połączeniu z regulacją stanu wód starorzecza była istotnym elementem programu. Przeprowadzono analizę możliwości zorganizowania na nowo układu wodnego, gdzie obecnie zarośnięte i zabagnione miejsca miały zostać oczyszczone. Regulacja i połączenie małych oczek wodnych pozwoliłaby w jakimś stopniu przywrócić dawne starorzecze i stworzyć większy akwen. Jak wiemy dawny zespół handlowych faktorii był zlokalizowany na wydzielonych wyspach odgrodzonych od lądu fosami. Planowany obszar wody byłby wykorzystany jako teren rekreacji i odpoczynku dla mieszkańców i zmęczonych turystów. Utworzenie większego zbiornika wodnego dawałoby szansę na jego turystyczne wykorzystanie i możliwość pływania małymi łódkami, co byłoby dodatkową atrakcją. Przyjęto zasadę iż od strony Pho Hien brzeg akwenu wodnego będzie umocniony nadbrzeżem, zaś po drogiej stronie, wzdłuż wału brzeg będzie umocniony faszyną. ety of functions, Pho Hien can become an attractive tourist destination. The concentration of functions in a small area and the diversification of the offering, as well as close contact with nature and the unique centre of education and culture planned in the trading factory will be of considerable significance here. The transformation of the existing contemporary, bland single-family residential development into a form relating to historical buildings was one of the challenges of the project. These buildings, along with new development, including the one designed to recreate the historical character of the site, were planned to become the fabric of the main street of Pho Hien and establish connections with the contemporary parts of the city. The name of the first route was Pho Hien Street Visitors Trail. It would lead outside the city and take visitors to the Longan groves and the historical complex of the trading factories. The second route, called the Natural Reserve Trail, would start at the same place, then run through the park and further along the levee of the Red River, ending in the complex of the trading factories. Connecting points were planned along both routes so as to give people an opportunity to create and take their own walks.

The construction of the complex of the former trading factories was a significant element of the project of revitalising Pho Hien. The scope of the project incorporated in the regulation of the prime minister of Vietnam also included the construction of replicas of three merchant ships. This part of the project entailed the creation of a centre of education and history there. This would enable attracting tourist interest that would be greater than the one given to several historical buildings so far.

\section{The revitalisation of the natural environment}

Carrying out the Pho Hien revitalisation project required conducting an analysis of historical sources as well as field and visual site analyses. The aim of all the analyses was to make the whole complex and the tours of the place attractive to tourists. The general principle adopted was that visitors should not be able to reach their place of interest appearing in view too quickly. Whether taking the urban or the natural trail, they would have an opportunity to discover attractions that would be missed along the original route. This would make tourists wander around the centre and visit craft workshops at the market place or take a rest in a scenic café at the waterfront. For that reason, designing green areas as well as regulating the water in the oxbow lakes in the old river bed was a significant part of the programme. A feasibility analysis of the water system's improvement, focused on the clearing of the existing overgrown and marshy areas, was conducted. The regulation as well as the connection of the oxbow lakes would enable both the partial restoration of the old river bed and the creation of a larger artifi- 
Przez tereny zielone miały być prowadzone ciągi piesze, które w atrakcyjny sposób poprzez mostki nad wodą powiązane byłyby z główną ulicą biegnącą przez dzielnicę. Jedne $z$ tych dróżek doprowadzały na wał rzeki Czerwonej, inne po drugiej głównej ulicy stronie powiązane były z parkingami i doprowadzałyby do centrum Hung Yen. Spacerując po wysokim wale rzeki Czerwonej turyści mogli ogląd zespół Pho Hien z innej perspektywy.

\section{Rewitalizacja zabudowy mieszkalnej}

Zabudowa przy głównej ulicy obecnie chaotyczna i z współczesnymi wysokimi domami musiała ulec korekcie. Przeprowadzono analizę stanu technicznego zabudowy i ich infrastruktury. Dawna parterowa zabudowa praktycznie nie spełniała nawet minimalnych standardów i nie nadawała się do dalszego wykorzystana na cele mieszkaniowe. Jednak stara zabudowa po adaptacji mogłaby dalej funkcjonować jako małe sklepiki czy warsztaty, a nawet małe kawiarnie z ogródkami. Zaproponowano by mieszkańcy tych domów uzyskali mieszkania w nowych budynkach zaplanowanych wzdłuż bocznych uliczek dochodzących do głównej ulicy. Domy te miały mieć dwie kondygnacje i ceramiczne dachy. Ich architektoniczny charakter nawiązywałby do tradycyjnej zabudowy.

Rzeczywistym problemem były nowe domy, jakie zostały współcześnie wybudowane, które obecnie sąsiadowały z dawnymi parterowymi domami. Miały one wysokie kondygnacje i na dodatek na ostatniej kondygnacji posiadały obecnie modne tarasy nakryte dachami. Domy o trzech kondygnacjach mając kondygnacje po 3,80-4 m wysokości wyraźnie górowały nad główną ulicą zasadniczo wpływając na zmianę jej charakteru. Tę sytuację należało doprowadzić do architektonicznego porządku. Podjęte zostały analizy architektoniczne cial lake. As we know, the original complex of trading factories was situated on man-made islands separated from the mainland by moats. The planned water area could be used as a recreation and relaxation area for both inhabitants and weary tourists. The construction of a larger artificial lake, where tourists could take boat rides, would provide one more tourist attraction. The adopted concept entailed embanking the lake shore with a waterfront on the Pho Hien side and strengthening the shore with a fascine on the levee side.

Pedestrian walkways and pathways running through the green areas would connect elegantly to the main street of the district via bridges over the water. Some of these paths would lead to the levee of the Red River, others, situated on the other side of the main street, would take people to car parks and the centre of Hung Yen. While walking along the high embankment of the Red River, tourists would be able to see the Pho Hien complex from a different perspective.

\section{The revitalisation of residential development}

The chaotic development of the main street with its contemporary high buildings had to be corrected. An analysis of the technical condition of the buildings and their infrastructure was conducted. The old one-storey buildings practically did not meet even the minimum standards and were no longer suitable for housing purposes. However, after adaptation, the old development could still function as small shops, workshops or even little cafés with outdoor tables. A proposal was made that the residents of those houses should be offered apartments in new buildings intended for construction along the side

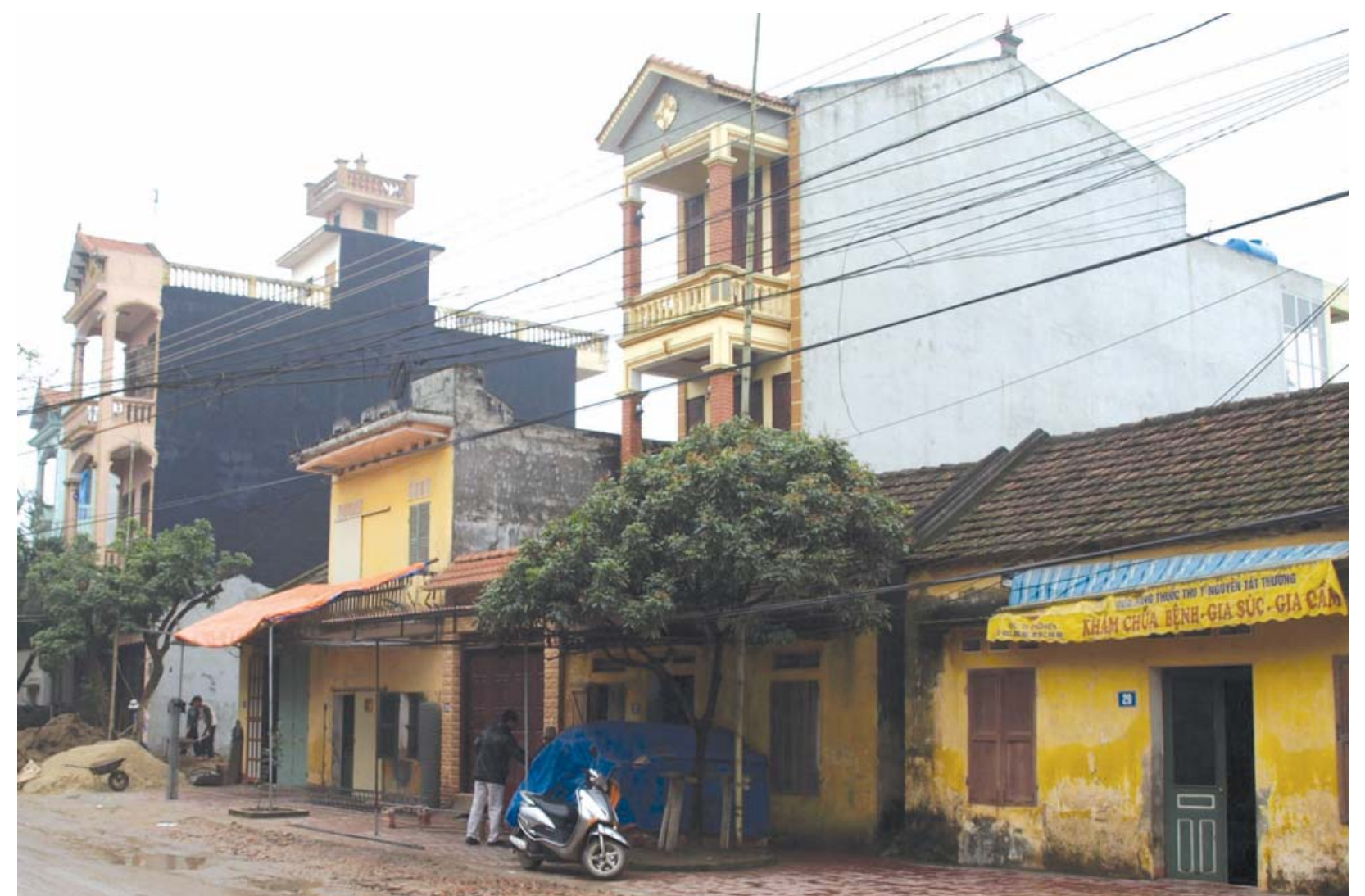




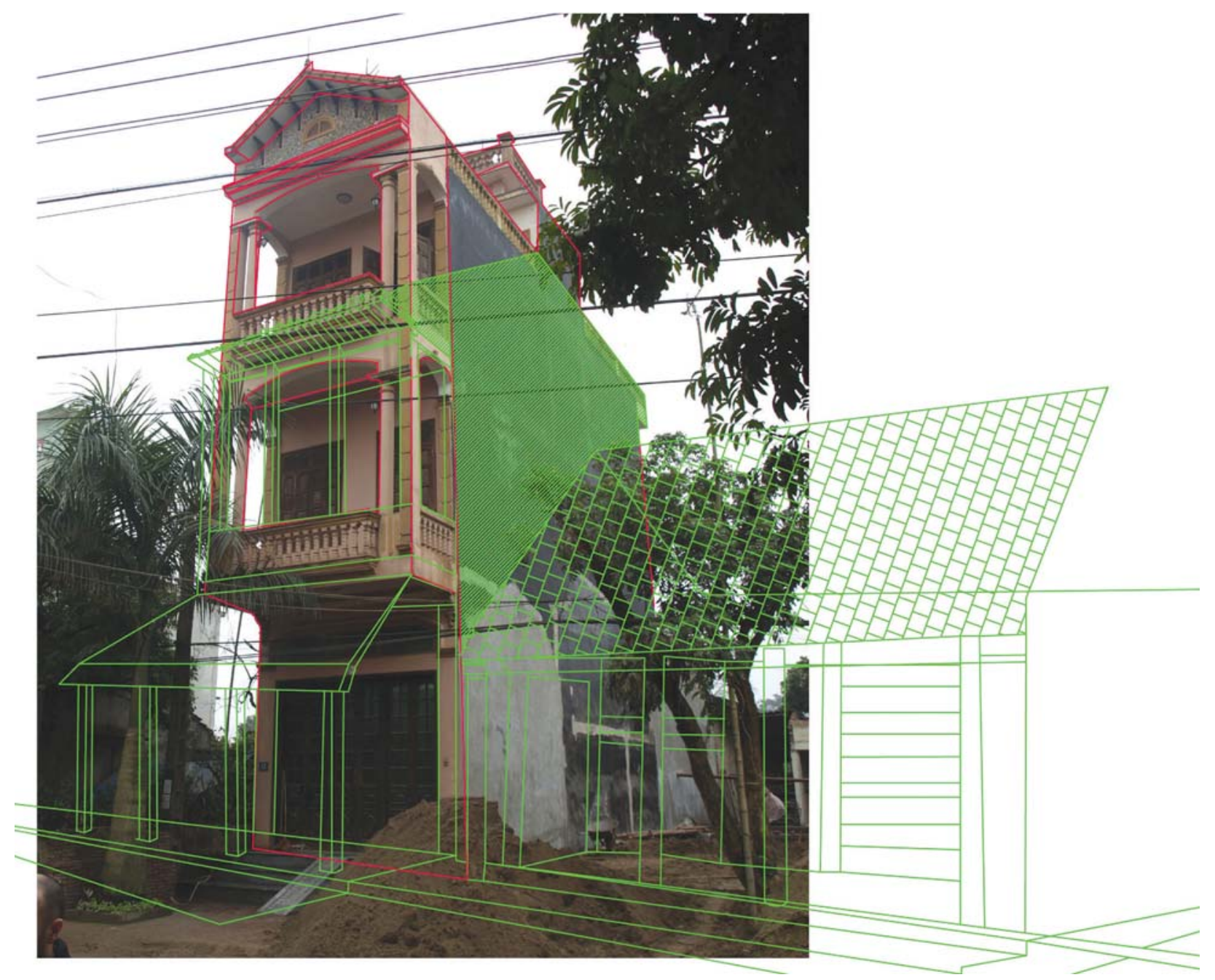

II. 6. Pho Hien, główna ulica nr 17, studium przekształcenia domu / Main street no 17, re-shaping study (P. Kinsner)

II. 7. Pho Hien. Widok ortogonalny istniejącej zabudowy nr 17-27 / Orthogonal view on houses nos. 17-27, present state (M. Zembrzuski)

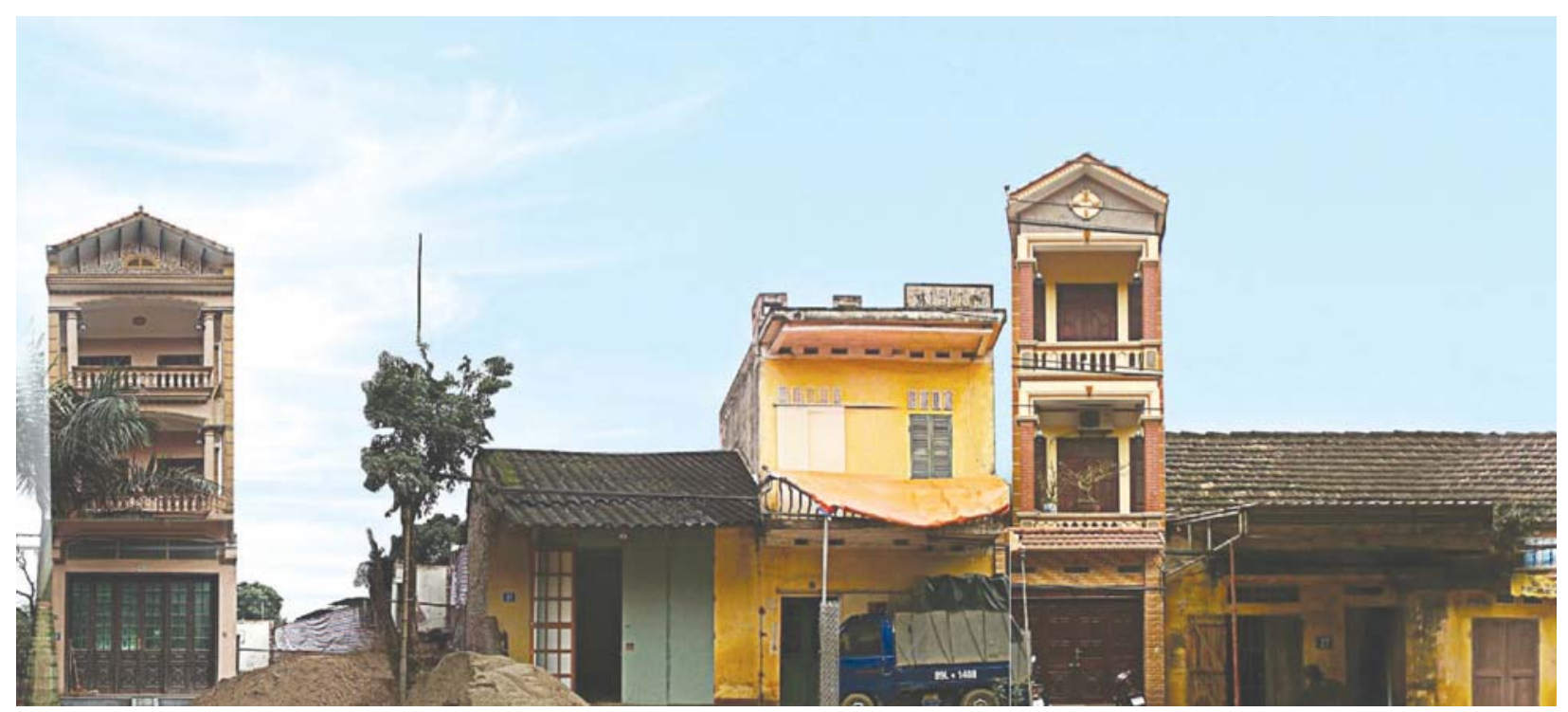




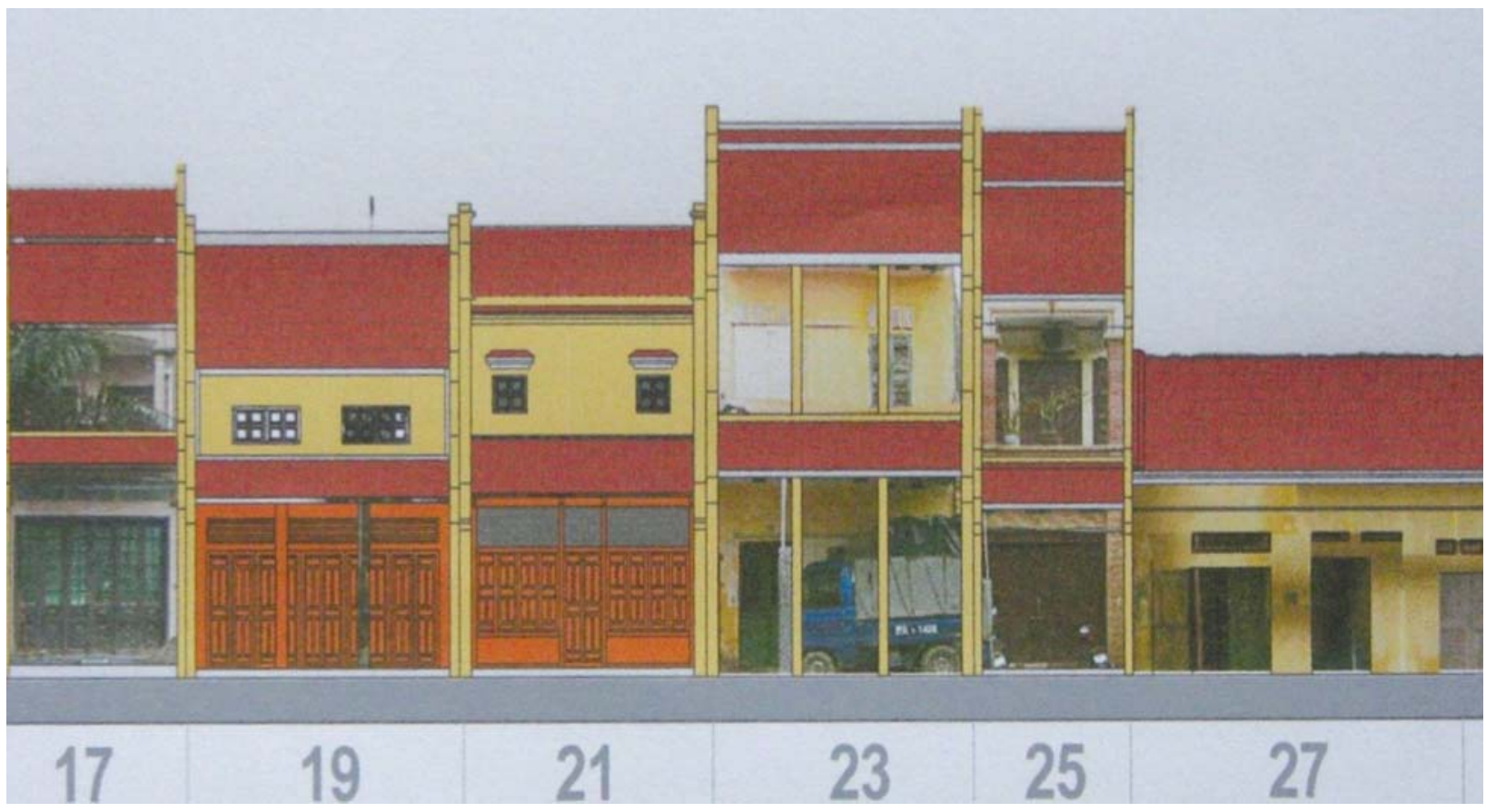

II. 8. Pho Hien. Propozycja rewitalizacji zabudowy nr 17-27 / Othogonal view on houses nos 17-27, reshaping (P.Kinsner)

mające na celu sprawdzenie możliwości przekształceń w nowych domach ostatnich kondygnacji by uzyskać przynajmniej od strony ulicy pochyłe ceramiczne dachy. Do samotnie stojących wysokich domy zaprojektowane zostały przybudówki, których dachy miały częściowo zasłonić puste ściany ogniowe. Przywrócenie ceramicznych dachów miało estetycznie porządkować wygląd głównej ulicy.

Pozostawiona na uboczu dzielnica praktycznie nie posiadała wydajnej kanalizacji, zaś rozprowadzenie wody zapewniała jej minimalną dostępność. Projekt rewitalizacji wobec zwiększonego użytkowania terenu założył streets leading to the main street. These houses were planned as two-storey buildings with ceramic-tiled roofs. Their architectural character would refer to the traditional development of that area.

The new houses, built contemporarily among the old one-storey buildings, were a real problem. They had high storeys and trendy covered rooftop terraces. The three-story houses, with floors 3.80-4 $\mathrm{m}$ in height each, visibly towered over the main street below, significantly affecting its character. These discrepancies had to be resolved and architectural order had to be brought back to the development. Architectural analyses were un-

II. 9. Pho Hien, Jeden z typów projektowanych nowych domów / Example of a new house design (P. Kinsner, H. Phu)

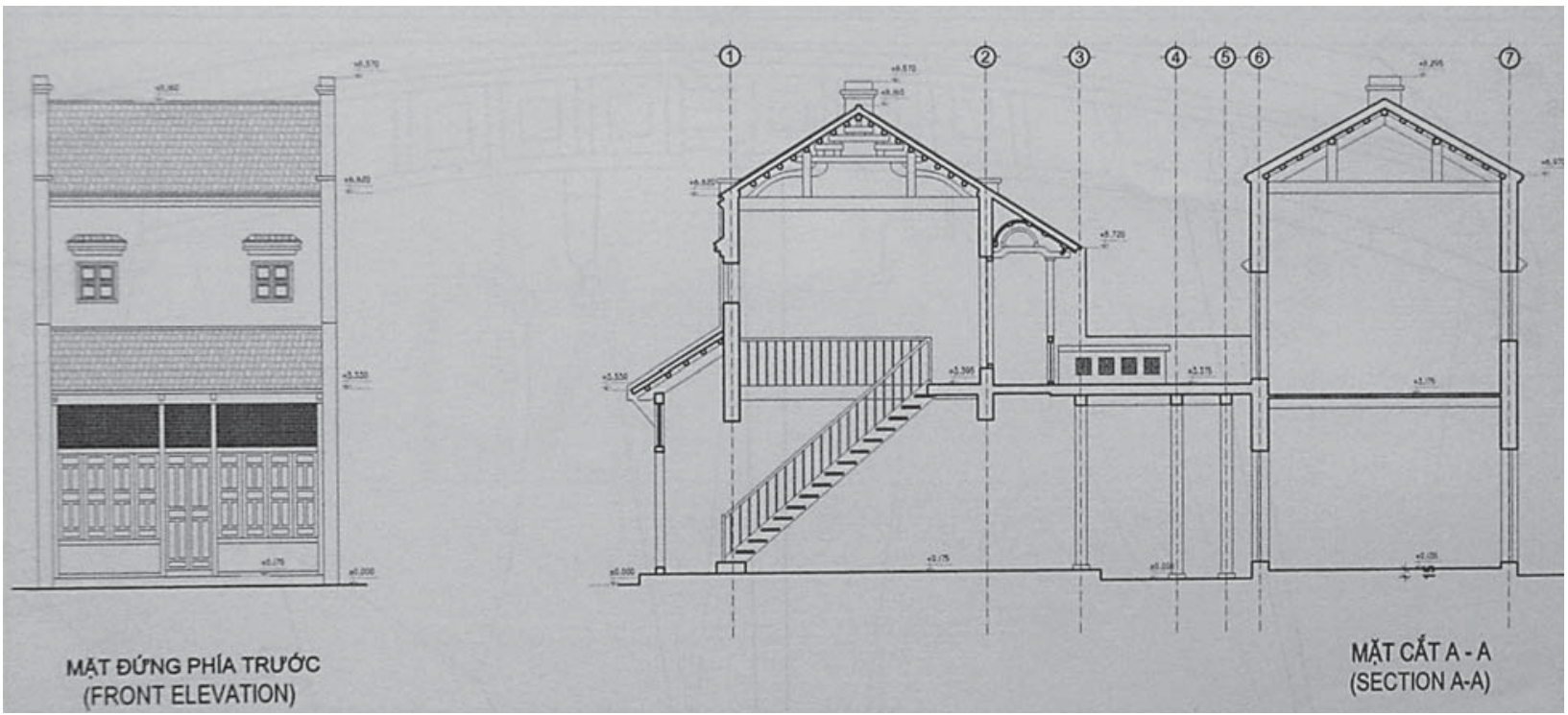




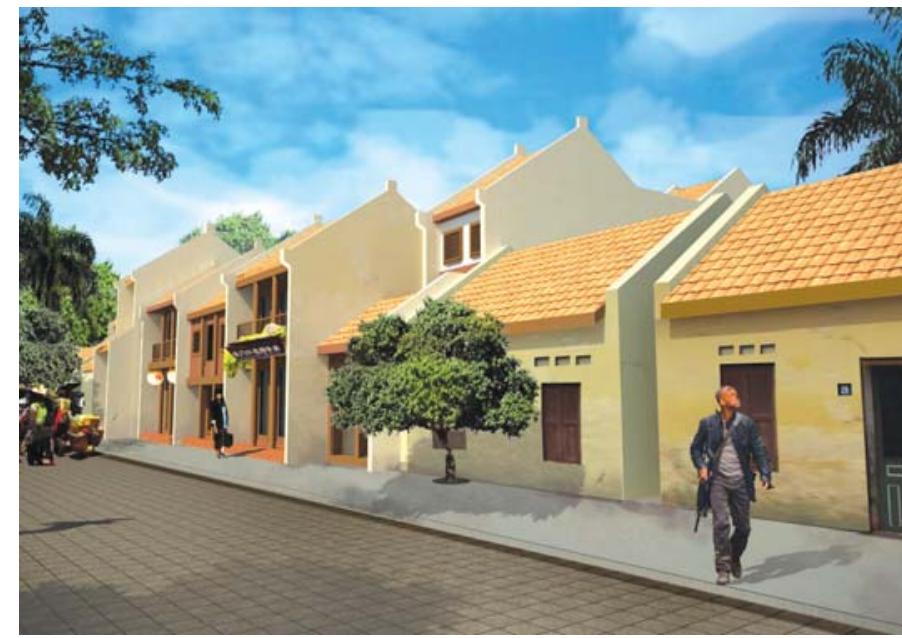

II. 10. Pho Hien. Główna ulica, wizualizacja odcinka nr. 17-29 / The Main Street, view on houses nos. 17-29 (P. Kinsner, M. Zembrzuski)

konieczność budowy systemu kanalizacji podłączonej do oczyszczalni ścieków, budowę nowego systemu zaopatrzenia w wodę i energię elektryczną.

\section{Zabytki}

Praktycznie wszystkie historyczne budowle świątynie, pagody, domy miały być poddane pracom konserwatorskim. Powstała jednak potrzeba zwiększenia ilości obiektów w stylu historycznym. Po wyburzeniu koszar w historycznej formie miała być odbudowana główna świątynia Pho Hien. Na wolnych działkach oraz po wyburzeniu kilku bezstylowych budynków i szkoły miały powstać repliki drewnianych domów reprezentujących lokalną architekturę.

Badania terenowe w okolicach Hung Yen wykazały iż miejscowa tradycyjna architektura wiejskich rezydencji posiada rozwiązania funkcjonalno-przestrzenne doskonale nadające się do wykorzystania jako małe kawiarnie, herbaciarnie czy sklepy. (Nguyen K., T., 1981; Nguyen, B., Nguyen V., P.,- Hoang, T., V., 2006, s. 42-44, 134-135). Rzeźbione w drewnie dekoracyjne elementy konstrukcji nadawały tym zabytkom atrakcyjności, której pozbawione były zachowane skromne małe domy w Pho Hien. Po wykonaniu inwentaryzacji kilku domów regionalnych zaproponowano ich budowę, co wzbogaciłoby stan historycznej zabudowy. Jednak domy te nie były dosyć duże by można było umieścić $w$ nich restaurację.

Dlatego zaproponowano by wykorzystać model dużego drewnianego domu w typie jakie zachowały się w Hoi An. (Phan, Matsumoto 2006) Wykonano inwentaryzację 3 typów obiektów jakie naszym zdaniem mogły być adaptowane w Pho Hien. Na potrzeby restauracji wybrano drewniany dom piętrowy z galerią na piętrze. Restaurację zlokalizowano na działce gdzie istniał piętrowy budynek administracyjny. Szczęśliwie dla nas budynek poprzedzony był dużym parkingiem, co pozwalało od strony ulicy wybudować replikę domu z Hoi An. Tam miały się znaleźć sale restauracyjne, zaś na zaplecze kuchenne adaptowałoby istniejący budynek.

Odrębnym zadaniem było zaprojektowanie zespołu targu. W dzisiejszym Hung Yen i Pho Hien brak jest zorganizowanego miejsca targowego. Codzienny targ i bazar odbywa się dertaken so as to check the street-facing top-floor terraces and roofs of the contemporary buildings for the feasibility of transformation into sloping ceramic-tiled roofs. Extensions with roofs partially covering the empty firewalls were designed for the high detached houses. The reintroduction of ceramic roofs was aimed at bringing aesthetic order to the appearance of the main street.

The district situated outside the centre effectively did not have an efficient sewage system, and water supply was available at minimum level. Due to the increased land use, the project of revitalisation assumed the necessity to build a sewage system connected to the sewage treatment plant as well as new water and electricity supply systems.

\section{Historical buildings}

Virtually all the historical temple buildings, pagodas and houses were planned to undergo conservation works. However, a necessity arose to increase the number of buildings in historical style. After the demolition of the military barracks, the rebuilding of the main temple of Pho Hien in its historical shape was planned. Replicas of wooden houses representing the local architecture were intended for construction on the vacated plots and the sites after the demolition of several styleless buildings and a school. Field analyses conducted in the Hung Yen province showed that the local traditional architecture of rich rural houses had functional and spatial solutions perfectly suitable for transformation into small cafés, tea houses or shops (Nguyen K., T., 1981; Nguyen, B., Nguyen V., P.,Hoang, T., V., 2006, p. 42-44, 134-135). The embellishments of the structural elements carved in wood gave the historical buildings an attractive look that the preserved little modest houses in Pho Hien lacked. After the preparation of a survey of several regional houses, a construction of similar buildings was proposed, with a view to enriching the existing historical development. However, the houses were not big enough to accommodate a restaurant.

Therefore, using the model of a large wooden house similar in type to the houses preserved in Hoi An was proposed (Phan, Matsumoto, 2006). A building survey of three types of structures suitable for adaptation in Pho Hien was prepared. A wooden two-storey house with a gallery on the first floor was selected for the restaurant. The construction of the restaurant was planned on a plot with a two-storey administration building. Luckily, the building had a big car park in front, which enabled the construction of a replica of a house from Hoi An facing the 
w określonych godzinach na wybranej ulicy, a owoce i warzywa sprzedawane są przez miejscową ludność w stoiskach organizowanych wzdłuż drogi przy wale powodziowym. Przeanalizowano formy zabudowy miejsc targowych w okolicznych miastach.(Nguyen, D., N., 1981) Dla zrównoważenia obsługi ruchu turystycznego w Pho Hien, na sąsiadującym obszarze przy wale rzeki, gdzie przewidziano wyburzenie dwu piętrowej starej szkoły, miano zlokalizować targ, od którego dalej po wale miał biec ciąg spacerowy. Takie rozwiązanie tworzyłoby turystyczną alternatywę dla ciągu głównej ulicy. Targ miałby układ kilku uliczek ze stoiskami przykrymi prostym zadaszeniem, Poszczególne uliczki stoisk zakończone byłyby z obu stron małymi budynkami gdzie mieściłyby się toalety oraz byłyby umywalnie. Jedna z uliczek mająca z tyłu wolną przestrzeń została zaplanowana na warsztaty produkcyjne. Turyści odwiedzający targ nie tylko mogliby nasycić się widokiem warzyw, owoców i ryb, ale również mieliby okazję poznać dawne tajniki produkcji ceramicznej czy wyrobów metalowych. Od strony miasta na targ wchodziłoby się przez bramę z umieszczonym na niej zadaszonym tarasem. Byłby to punkt widokowy na Pho Hien i płynąca w oddali rzekę Czerwoną. Z drugiej strony targ wychodziłby na utworzony akwen. $Z$ nadbrzeża przy targu widać byłoby drewniany most, a za nim centrum dawnych faktorii i maszty statków zacumowane przy ich nabrzeżu.

\section{Centrum kulturalno-edukacyjne}

Jednym z celów projektu było podkreślenie dawnej roli Pho Hien w międzynarodowym handlu morskim . Pod względem formalnym ten historyczny związek miał być zaakcentowany budową budynków faktorii i replik street. The replica was to accommodate restaurant rooms, and the existing building was intended to be changed into a kitchen and the kitchen backroom.

Designing the market complex was another task. There is no fixed market place in Hung Yen and Pho Hien today. The daily market and bazaar are held at specific times, on a selected street, and fruit and vegetables are sold by local people from stalls placed along the road by the levee. The forms of market place developments existing in the nearby townlets were analysed (Nguyen, D., N., 1981). In order to balance the tourist services in Pho Hien, in the neighbouring area by the river levee, where a two-storey school was intended for demolition, a market place was planned with a walkway running out of it on the levee. Such a solution would give tourists an alternative to the main street. The market place would have a layout of several alleys with stalls covered with simple rooftops. The individual alleys would have toilets and tap water in small buildings situated at both ends. One of the alleys with free space at the back was intended for manufacturing workshops. Tourists visiting the market place would have an opportunity to delight in the fruit, vegetables and fish displayed there as well as to learn the old secrets of ceramic and metal production. Form the side of the city, the market place would be entered through a gate with a roofed terrace over it. This would be an observation deck with a view of Pho Hien and the Red River flowing in the distance. The other side of the market place would overlook the artificial lake.

II. 11. Pho Hien. Propozycja zabudowy centrum edukacyjnego (dawne faktorie handlowe) / Architectural proposal for education and historical center (old trading factory buildings) (M. Barański, M. Zembrzuski

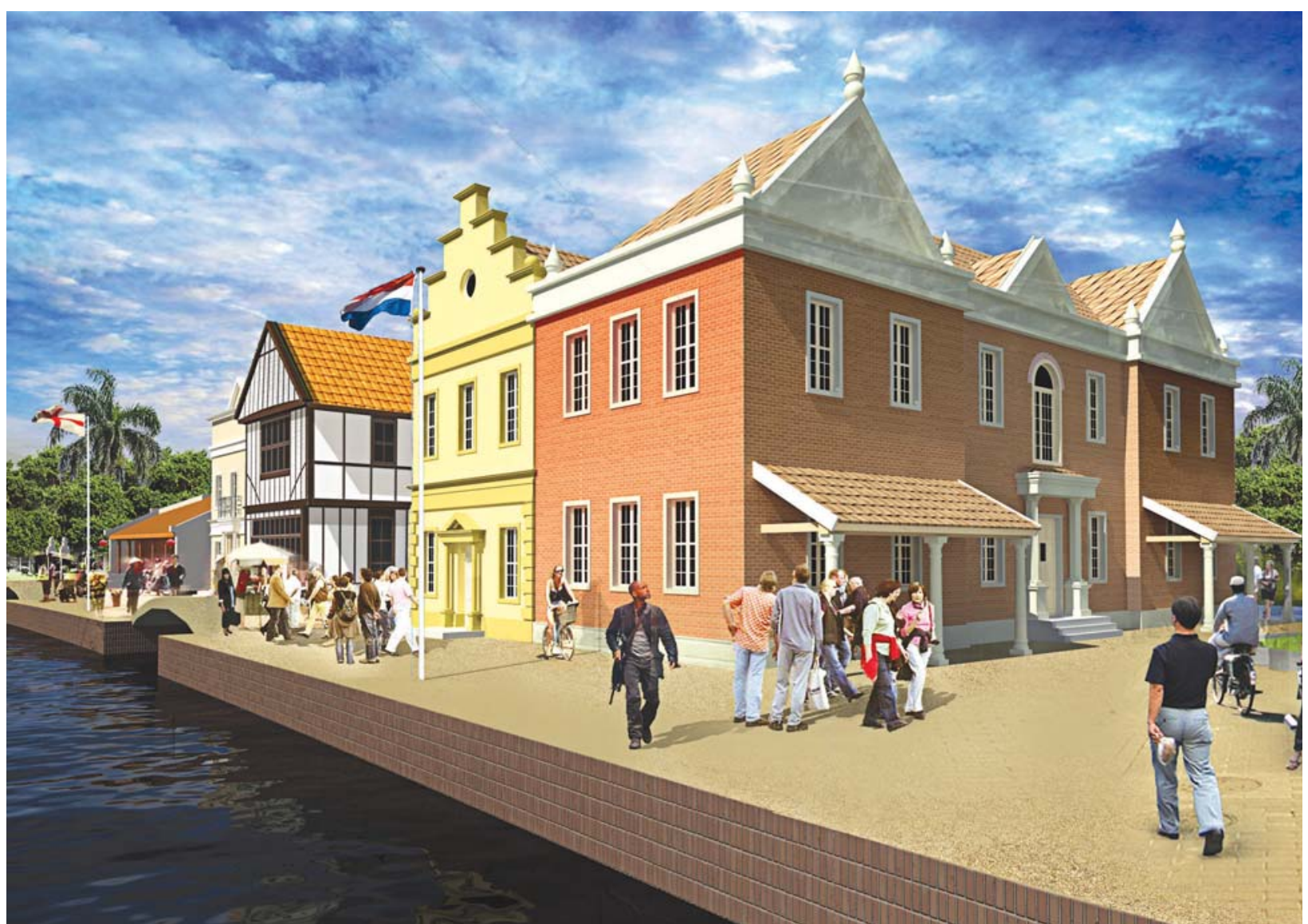


i pierwszy Polak Michał Boym, autor słynnego albumu „Flora Sinensis" który w 1647 właśnie przez Pho Hien przybył do Wietnamu. (Kajdański 1988; 1999; Boym, 1994, s. 84; Nguyen D., N., 2000; 2006, s. 8299, 226-250) Stworzenie bogatego programu ekspozycyjno - edukacyjnego wraz z ekspozycją historycznych statków miało nadać temu miejscu cechy unikatowe i łatwo wyróżniające Pho Hien na mapie turystycznych destynacji w Wietnamie.

\section{Zakończenie}

Wykonany przez polskich architektów projekt rewitalizacyjny, uzyskał wsparcie ze strony rządu polskiego, który uznał możliwość jego realizacji poprzez udzielenie stronie wietnamskiej wieloletniego kredytu rozwojowego. Mimo takiej możliwości ekonomicznego wsparcia projektu, lokalne władze prowincji Hung Yen nie uzyskały rekomendacji władz w Hanoi dla wystąpienia o środki na przeprowadzenie rewitalizacji dzielnicy Pho Hien.

\section{LITERATURA}

[1] Barański, M., 2016, World Heritage in Hue (Vietnam). Its degradation and preventive measures in: Gambardella, C., (ed.) World Heritage and Degradation. Smart Design, Planning and Technologies, Neaples, Wydawnictwo: Scuola Pitagora Editrice, s. 529-536

[2] Baron, S., 1732, Description of the Kingdom of Tonqueen (1685) in: Awsham and John Churchill (eds.), A Collection of Voyages and Travels, 6 vol., London,

[3] Boxer C., R., 1990, The Dutch Seaborne Empire 1600-1800, London, Wydawnictwo: Penguin Books

[4] Boym, M., P., 1994, Raport z Królestwa Syjamu, in: Antoni Kuczyński (ed.), Polskie opisanie świata. Studia z dziejów poznania kultur ludowych i plemiennych. T.1, Azja i Afryka, Wrocław, Wydawnictwo: Uniwersytet Wrocławski

[5] Chau, H., 2006, Ngouoi Hoa O Pho Hien Trong Moi Quan hw Voi Nguoi Hoa o Cac Do Thi Viet Nam Cung Thoy Ky [The Chinese in Pho Hien and their relations with other Chinese in other urban areas of Vietnam] in: Nguyen, D., N, (ed.) 2006, Pho Hien, Ky yen Hoi thao Khoa hoc Pho Hien [Pho Hien, the Centre of International Commerce in the 17th-18th Centuries] (conference 1994). Hung Yen Wydawnictwo: The Association of Vietnamese Historians and People's Committee of Hai Hung Province, s. $202-209$

[6] Dror, O., Taylor, K., 2006, Views of Seventheenth-Century Vietnam: Christophoro Borri on Cochinchina and Samuel Baron on Tonkin, Ithaca NY; Wydawnictwo: Cornell University Press

[7] Farrinngton, A., 2002, The East India Company and Asia, London; Wydawnictwo: British Museum,

[8] Farrinngton, A., 2006, Ngung tai lieu cua Cong ty Dong An Anh lien quan den Pho Hien va Dang Ngoai [The English East India Company Documents Relating Pho Hien and Tonkin] in: Nguyen, D., N., (ed.) 2006, Ky yen Hoi thao Khoa hoc Pho Hien (Pho Hien, the Centre of International Commerce in the 17th-18th Centuries] (conference 1994), Hung Yen; Wydawnictwo: The Association of Vietnamese Historians and People's Committee of Hai Hung Province, s. 143- 159

[9] Grise, Ch., Nguyen, N., Q., 1999, Preserving Hanoi's Architectural and landscape Heritage, Hanoi, Wydawnictwo: Construction Publishing House, [10] Hoang, A., T., 2007, Silk for Silver: Dutch-Vietnamese Relation 16371700, Leiden, Wydawnictwo: Brill

[11] Kajdański, E., 1988, Michał Boym, Ostatni wysłannik dynastii Ming, Warszawa, Wydawnictwo: Polonia;

[12] Kajdański, E., 1999, Michał Boym, Ambasador Państwa Środka, Warszawa, Wydawnictwo: Książka i Wiedza

[13] Kwiatkowski, K., 1990, Problémes de conservation de la vieille ville de Hoin An, [w:] Kwiatkowski (ed.) 1990, s. 51-52

[14] Kwiatkowski, K., (ed), 1990, Recherches sur les monumentes du Champa. Rapport de la mission Polono- Vietnamienne 1983-1986, Varsovie, Wydawnictwo PP PKZ

[15] Maybon, Ch., B., 1910, Une factorerie anglaise au Tonkin an XVIle siècle (1872-1697) , w: Bulletin de l'Ecole francaise d'Extréme-Orient, 10, s. 159-204;

[16] Nguyen, B., D., Nguyen, V., P.,- Hoang, T., V., 2006, Traditional Vietnamese Architecture, Hanoi, Wydawca: The Gioi Publishers

[17] Nguyen, D., N., 1981, The Rural Markets (Cho-Lang) of Northern Vietnam, in: Vietnamese Studies vol. 65 (17th year), Traditional Village, vol. II, Hanoi 1981, s. 72-130 arrived in Vietnam coming ashore in Pho Hien in 1647 (Kajdański 1988; 1999; Boym, 1994, 84, Nguyen, D., N., 2000; 2006, p. 82-99, 226-250). The development of a rich exhibition and educational programme along with the replicas of historical ships on display was intended to give the place a quality of uniqueness and to distinguish Pho Hien on the map of tourist destinations in Vietnam.

\section{Conclusion}

The revitalisation project developed by a group of Polish architects received support from the Polish government, which recognised the possibility of its implementation by granting the Vietnamese party a long-term development loan. Despite such an opportunity of economic support for the project, the local authorities of the Hung Yen province did not receive a recommendation from the authorities in Hanoi to apply for the funds for the revitalisation of the Pho Hien district.

\section{REFERENCES}

[1] Barański, M., 2016, World Heritage in Hue (Vietnam). Its degradation and preventive measures in: Gambardella, C., (ed.) World Heritage and Degradation. Smart Design, Planning and Technologies, Neaples, Wydawnictwo: Scuola Pitagora Editrice, s. 529-536 [2] Baron, S., 1732, Description of the Kingdom of Tonqueen (1685) in: Awsham and John Churchill (eds.), A Collection of Voyages and Travels, 6 vol., London,

[3] Boxer C., R., 1990, The Dutch Seaborne Empire 1600-1800, London, Wydawnictwo: Penguin Books

[4] Boym, M., P., 1994, Raport z Królestwa Syjamu, in: Antoni Kuczyński (ed.), Polskie opisanie świata. Studia z dziejów poznania kultur ludowych i plemiennych. T.1, Azja i Afryka, Wrocław, Wydawnictwo: Uniwersytet Wrocławski

[5] Chau, H., 2006, Ngouoi Hoa O Pho Hien Trong Moi Quan hw Voi Nguoi Hoa o Cac Do Thi Viet Nam Cung Thoy Ky [The Chinese in Pho Hien and their relations with other Chinese in other urban areas of Vietnam] in: Nguyen, D., N, (ed.) 2006, Pho Hien, Ky yen Hoi thao Khoa hoc Pho Hien [Pho Hien, the Centre of International Commerce in the 17th-18th Centuries] (conference 1994), Hung Yen Wydawnictwo: The Association of Vietnamese Historians and People's Committee of Hai Hung Province, s. 202-209

[6] Dror, O., Taylor, K., 2006, Views of Seventheenth-Century Vietnam: Christophoro Borri on Cochinchina and Samuel Baron on Tonkin, Ithaca NY; Wydawnictwo: Cornell University Press

[7] Farrinngton, A., 2002, The East India Company and Asia, London; Wydawnictwo: British Museum,

[8] Farrinngton, A., 2006, Ngung tai lieu cua Cong ty Dong An Anh lien quan den Pho Hien va Dang Ngoai [The English East India Company Documents Relating Pho Hien and Tonkin] in: Nguyen, D., N., (ed.) 2006, Ky yen Hoi thao Khoa hoc Pho Hien [Pho Hien, the Centre of International Commerce in the 17th-18th Centuries] (conference 1994), Hung Yen; Wydawnictwo: The Association of Vietnamese Historians and People's Committee of Hai Hung Province, s. 143- 159

[9] Grise, Ch., Nguyen, N., Q., 1999, Preserving Hanoi's Architectural and landscape Heritage, Hanoi, Wydawnictwo: Construction Publishing House,

[10] Hoang, A., T., 2007, Silk for Silver: Dutch-Vietnamese Relation 1637-1700, Leiden, Wydawnictwo: Brill

[11] Kajdański, E., 1988, Michał Boym, Ostatni wysłannik dynastii Ming, Warszawa, Wydawnictwo: Polonia;

[12] Kajdański, E., 1999, Michał Boym, Ambasador Państwa Środka, Warszawa, Wydawnictwo: Książka i Wiedza

[13] Kwiatkowski, K., 1990, Problémes de conservation de la vieille ville de Hoin An, [w:] Kwiatkowski (ed.) 1990, s. 51-52

[14] Kwiatkowski, K., (ed), 1990, Recherches sur les monumentes du Champa. Rapport de la mission Polono- Vietnamienne 19831986, Varsovie, Wydawnictwo PP PKZ

[15] Maybon, Ch., B., 1910, Une factorerie anglaise au Tonkin an XVIle siècle (1872-1697), w: Bulletin de I'Ecole francaise d'Extréme-Orient, 10, s. 159-204;

[16] Nguyen, B., D., Nguyen, V., P.,- Hoang, T., V., 2006, Traditional Vietnamese Architecture, Hanoi, Wydawca: The Gioi Publishers 
[18] Nguyen, D., N., (ed.) 2006, Ky yen Hoi thao Khoa hoc Pho Hien IPho Hien the Centre of International Commerce in the 17th-18th Centuries] (conference 1994), Hung Yen, Wydawnictwo: The Association of Vietnamese Historians and People's Committee of Hai Hung Province,

[19] Nguyen, D., N., 2000, Okoliczności pobytu Michała Boyma w Tonkinie (północny Wietnam w XVII wieku, w: Odrodzenie i reformacja w Polsce, R. 44, s. 149-154

[20] Nguyen, D., N., 2006, Polscy misjonarze na Dalekim Wschodzie W XVII-XVIII wieku, Warszawa, Wydawnictwo: Neriton

[21] Nguyen, K., T., 1981, The Village Settlement of Peasants in Northern Vietnam, in: Vietnamese Studies vol. 65 (17th year) Traditional Village, vol. II, Hanoi, s. 7-45

[22] Nguyen, L., K., 2013, Arts of Vietnam 1009-1945, Hanoi, Wydawnictwo: The Ghoi Publishers,

[23] Nguyen, Q., N., 2006. Doi Net Ve Cong Ty Dong An Ha Lan Va Thuong Diem Pho Hien [Some Features on Dutch East India Company and its Trade Office at Pho Hien] in: Nguyen, D., N., (ed.) 2006, Ky yen Hoi thao Khoa hoc Pho Hien [Pho Hien, the Centre of International Commerce in the 17th-18th Centuries] (conference 1994), Hung Yen; Wydawnictwo: The Association of Vietnamese Historians and People's Committee of Hai Hung Province, s. 129-137

[24] Nguyen T., H., Pho Hien Qua Cac Nguon Tu Lieu Nuoc Ngoai [Pho Hien Seen from foreign sources], in: Nguyen, D., N., (ed.) 2006, Ky yen Hoi thao Khoa hoc Pho Hien [Pho Hien, the Centre of International Commerce in the 17th-18th Centuries] (conference 1994). Hung Yen, Wydawnictwo: The Association of Vietnamese Historians and People's Committee of Hai Hung Province, s.83-88

[25] Olszewski, W., 1991, Historia Wietnamu, Wrocław, Wydawnictwo Ossolineum:

[26] Pham H.,T., (ed.), 2008, Di Tich, Lich Su-Van Hoa Hung Yen, [Cultural and Historic Relicts in Hung Yen Province], Hung Yen, Wydawnictwo: Bao Tang Hung Yen

[27] Phan, H., L., Matsumoto, A., (eds.), 2006, Kien truc pho co Hoi An Vietnam, Hanoi, Wydawnictwo: The Gioi Publishers

28] Phuong, D., Q., 2011, Village Architecture in Hanoi: Patterns and Changes, Hanoi, Wydawnictwo: Science and Technics Publishing House

[29] Schweyer, A., V., 2011, Ancient Vietnam, Art and Archaeology, Bangkok, Wydawnictwo: River Books

[30] Tang Ba Hoanh, 2006, Di Tich Lich Su Van Hoa o Pho Hien, [Cultural and Historic Relicts in Pho Hien], in: Nguyen, D., N., (ed.) 2006 Ky yen Hoi thao Khoa hoc Pho Hien [Pho Hien, the Centre of Inter-

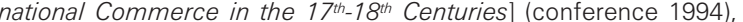
Hung Yen, Wydawnictwo: The Association of Vietnamese Historians and People's Committee of Hai Hung Province, s. 221-227, [31] Truong H., Q., 2006, Su ra doi va phat trien cua Phn Hien (The Birth of Pho Hien), in: Nguyen, D., N., (ed.) 2006, Ky yen Hoi thao Khoa hoc Pho Hien [Pho Hien, the Centre of International Commerce in the 17th-18th Centuries] (conference 1994). Hung Yen, Wydawnictwo: The Association of Vietnamese Historians and People's Committee of Hai Hung Province, s. 36-44

[32] Tran T., V., Than Long- Pho Hien Noi Quan He Giao Thung o The Ky XVI-XVII [Commercial relations between Thang Long and Pho Hien in the $17^{\text {th }}-18^{\text {th }}$ centuries], in: Nguyen, D., N., (ed.) 2006 , Ky yen Hoi thao Khoa hoc Pho Hien [Pho Hien, the Centre of International Commerce in the 17th-18th Centuries] (conference 1994), Hung Yen, , Wydawnictwo: The Association of Vietnamese Historians and People's Committee of Hai Hung Province, s. 196-201

[33] Wills Jr. J, E., 1974, Pepper Guns and Company and Parleys: The Dutch East India Company and China 1662-1687, Cambridge; Wydawnictwo: Harvard University Press

[34] Vu, H., T., (ed.), 2011, Ancient Town of Hoi An ,Hanoi, Wydawnictwo: The Gioi Publishers

[35] Winterbottom A., 2013, Self - Fashioning and Auto - Ethnography. Samuel's Baron's Description of Tonqueen (1686), in: Journeys, vol. 14, Dec., p. 85-105
17] Nguyen, D., N., 1981, The Rural Markets (Cho-Lang) of Northern Vietnam, in: Vietnamese Studies vol. 65 (17th year), Traditional Village, vol. II, Hanoi 1981, s. 72-130

[18] Nguyen, D., N., (ed.) 2006, Ky yen Hoi thao Khoa hoc Pho Hien [Pho Hien, the Centre of International Commerce in the 17th-18th Centuries (conference 1994), Hung Yen, Wydawnictwo: The Association of Vietnamese Historians and People's Committee of Hai Hung Province,

[19] Nguyen, D., N., 2000, Okoliczności pobytu Michała Boyma w Tonkinie (północny Wietnam w XVII wieku, w: Odrodzenie i reformacja w Polsce, R. 44, s. 149-154

[20] Nguyen, D., N., 2006, Polscy misjonarze na Dalekim Wschodzie w XVII-XVIII wieku, Warszawa, Wydawnictwo: Neriton

[21] Nguyen, K., T., 1981. The Village Settlement of Peasants in Northern Vietnam, in: Vietnamese Studies vol. 65 (17th year) Traditional Village, vol. II, Hanoi, s. 7-45

[22] Nguyen, L., K., 2013, Arts of Vietnam 1009-1945, Hanoi, Wydawnictwo: The Ghoi Publishers,

[23] Nguyen, Q., N., 2006, Doi Net Ve Cong Ty Dong An Ha Lan Va Thuong Diem Pho Hien [Some Features on Dutch East India Company and its Trade Office at Pho Hien] in: Nguyen, D., N., (ed.) 2006, Ky yen Hoi thao Khoa hoc Pho Hien [Pho Hien, the Centre of International Commerce in the 17th-18th Centuries] (conference 1994), Hung Yen; Wydawnictwo: The Association of Vietnamese Historians and People's Committee of Hai Hung Province, s. 129-137

[24] Nguyen T., H., Pho Hien Qua Cac Nguon Tu Lieu Nuoc Ngoai [Pho Hien Seen from foreign sources], in: Nguyen, D., N., (ed.) 2006, Ky yen Hoi thao Khoa hoc Pho Hien [Pho Hien, the Centre of International Commerce in the 17th-18th Centuries] (conference 1994). Hung Yen, Wydawnictwo: The Association of Vietnamese Historians and People's Committee of Hai Hung Province, s.83 -88

[25] Olszewski, W., 1991, Historia Wietnamu, Wrocław, Wydawnictwo Ossolineum

[26] Pham H., T., (ed.), 2008, Di Tich, Lich Su-Van Hoa Hung Yen, [Cultural and Historic Relicts in Hung Yen Province], Hung Yen, Wydawnictwo: Bao Tang Hung Yen:

[27] Phan, H., L., Matsumoto, A., (eds.), 2006, Kien truc pho co Hoi An Vietnam, Hanoi, Wydawnictwo: The Gioi Publishers

[28] Phuong, D., Q., 2011, Village Architecture in Hanoi: Patterns and Changes, Hanoi, Wydawnictwo: Science and Technics Publishing House

[29] Schweyer, A., V., 2011, Ancient Vietnam, Art and Archaeology, Bangkok, Wydawnictwo: River Books,

[30] Tang Ba Hoanh, 2006, Di Tich Lich Su Van Hoa o Pho Hien, [Cultural and Historic Relicts in Pho Hien], in: Nguyen, D., N., (ed.) 2006 Ky yen Hoi thao Khoa hoc Pho Hien [Pho Hien, the Centre of International Com merce in the 17 th-18 th Centuries] (conference 1994). Hung Yen, Wydawnictwo: The Association of Vietnamese Historians and People's Committee of Hai Hung Province, s. 221-227,

[31] Truong H., Q., 2006, Su ra doi va phat trien cua Phn Hien (The Birth of Pho Hien) in: Nguyen, D. N., (ed.) 2006, Ky yen Hoi thao Khoa hoc Pho Hien [Pho Hien, the Centre of International Commerce in the 17th-18th Centuries] (conference 1994), Hung Yen, Wydawnictwo: The Association of Vietnamese Historians and People's Committee of Hai Hung Province, s. $36-44$

[32] Tran T., V., Than Long- Pho Hien Noi Quan He Giao Thung o The Ky XVI- XVII [Commercial relations between Thang Long and Pho Hien in the $17^{\text {th }}-18^{\text {th }}$ centuries], in: Nguyen, D., N., (ed.) 2006, Ky yen Hoi thao Khoa hoc Pho Hien IPho Hien the Centre of International Commerce in the 17th-18th Centuries] (conference 1994), Hung Yen, , Wydawnictwo: The Association of Vietnamese Historians and People's Committee of Hai Hung Province, s. 196-201

[33] Wills Jr. J, E., 1974, Pepper Guns and Company and Parleys: The Dutch East India Company and China 1662-1687, Cambridge; Wydawnictwo: Harvard University Press

[34] Vu, H., T., (ed.), 2011, Ancient Town of Hoi An ,Hanoi, Wydawnictwo: The Gioi Publishers

[35] Winterbottom A., 2013, Self - Fashioning and Auto - Ethnography. Samuel's Baron's Description of Tonqueen (1686), in: Journeys, vol. 14 Dec., p. 85-105 